ROCZNIKI TEOLOGICZNE

Tom LXVII, zeszyt $10-2020$

DOI: http://dx.doi.org/10.18290/rt206710-4

KAROLINA KOMSTA-TOKARZEWSKA

\title{
OBRAZ SIEBIE U MĘŻCZYZN UZALEŻNIONYCH OD INTERNETU. ANALIZA PORÓWNAWCZA
}

\author{
SELF-IMAGE OF MEN ADDICTED TO THE INTERNET. \\ COMPARATIVE ANALYSIS
}

\begin{abstract}
Self-image constitutes an axial element of the human personality structure that regulates their behaviour. It plays an important role in the self-regulation process. Internet addiction is a disorder, the main symptom of which is the loss of self-regulating abilities and control of one's behaviour in relation to the machine, which is the result of, inter alia, functioning of mechanisms that distort self-perception. The following article presents the results of a comparative analysis carried out on a group of 70 men addicted to the Internet and 66 non-addicted men, within the self-image structure measured by the Adjective Check List (ACL) by B. B. Gough and A. B. Heilbrun. Research results indicate that there are statistically significant differences in the structure of self-image within both groups. Purposive sampling and small sample size $(\mathrm{N}=136)$ limit the scope of inference, however, they have a significant application value, which is worth considering while designing preventive and therapeutic interventions strengthening deficit areas in addicts.
\end{abstract}

Key words: Self-image; Internet addiction.

\section{OBRAZ SIEBIE A UZALEŻNIENIE OD INTERNETU}

Problematyka obrazu siebie stanowi jedno z kluczowych pojęć dla nauk społecznych. Pojęcie to zostało wprowadzone przez ojca amerykańskiej psychologii Williama Jamesa w 1980 roku w książce Principles of Psychology. James uważał, że ,ja” to świadomość samego siebie, całość procesów psychicznych, ale również to wszystko, co nazywamy swoim własnym.

Dr Karolina Komsta-ToKarzewsKa - Katedra Nauk o Rodzinie, Instytut Nauk Teologicznych, Katolicki Uniwersytet Lubelski Jana Pawła II; adres do korespondencji: Al. Racławickie 14, 20-950 Lublin; e-mail: karolina.komsta@kul.lublin.pl; ORCID: https://orcid.org/0000-0002-63153990. 
Jak wskazuje literatura przedmiotu, termin ten przebył długą drogę począwszy od czasów psychoanalizy, aż do chwili obecnej. W koncepcjach psychoanalitycznych zwracano uwagę na dynamiczny charakter struktury osobowości człowieka. Do utrzymania stabilnego obrazu struktura Ego posługuje się mechanizmami obronnymi, takimi jak: racjonalizacja, wyparcie, fiksacja, formacja reaktywna czy projekcja ${ }^{1}$.

Koncepcje behawiorystyczne zakładają, że nie istnieje życie intrapsychiczne człowieka. W podejściu tym nie używa się takich pojęć, jak „osobowość” czy „obraz siebie”, terminy te zastępuje się pojęciem ,zachowanie”2. Według założeń tego nurtu człowiek jest istotą zewnątrz sterowną, a jego postępowanie wynika z oddziaływań środowiskowych.

W ujęciu teorii poznawczych „obraz siebie” jest konstruktem wielowymiarowym, definiowanym jako „,samoświadomość" lub jako „samowiedza”3. Rozważania naukowe na gruncie paradygmatu poznawczego doprowadziły do wyłonienia się pojęcia ,ja normatywnego", traktowanego jako struktura pierwotna wobec ,ja idealnego". W przypadku osób uzależnionych od Internetu mamy do czynienia z sytuacją, w której następują zaburzenia na poziomie funkcji regulacyjnej ,ja”, która odpowiada za ocenę własnych możliwości, $\mathrm{w}$ tym ocenę związaną z podejmowaniem zachowań ryzykownych w sieci. W oparciu o literaturę przedmiotu można przyjąć, że ,ja” osoby uzależnionej ma specyficzne właściwości odmienne dla osób wolnych od nałogów, przyczyniające się do zaburzeń samoregulacji. Stoi to w zgodności z przedstawicielami tak zwanych teorii diagnostycznych w nurcie badań nad czynnikami ryzyka uzależnienia od Internetu, zgodnie z którymi traktuje się internetową zależność jako zaburzenie kontroli nawyków i popędów o przebiegu niechemicznym niepowodujące intoksykacji, jednak istotnie i wyraźnie pogarszające funkcjonowanie człowieka we wszystkich sferach jego życia ${ }^{4}$. O pośrednim związku samoświadomości z podejmowaniem zachowań nałogowych można wnioskować na postawie badań nad osobami uzależnionymi substancjalnie. Autorzy, tacy jak R. Baumeister, T.F. Heatherton, D. Tice, wykazali istotność statystyczną związku samooceny i samoświadomości u osób uzależnionych od alkoholus. Chociaż osoby o niskiej samoocenie miały silniejszą tendencję do

\footnotetext{
${ }^{1}$ J. Strelau, Podręcznik akademicki, t. II. Podstawy psychologii, Gdańsk 2004, s. 24.

2 J. KozIELECKI, Koncepcje psychologiczne człowieka, Warszawa 1995, s. 41.

${ }^{3}$ B. Kostrubiec, Obrazy postmodernizmu, Lublin 2004, s. 12.

${ }^{4}$ K.S. Young, Addictive Use of The Internet: A Case Study that Breaks The Stereotype, „Psychological Reports" 79(1996), s. 901.

${ }^{5}$ R. BAumeister, T. HeAtherton, D. Tice, Utrata kontroli. Jak i dlaczego tracimy zdolność samoregulacji, Państwowa Agencja Rozwiązywania Problemów Alkoholowych, Warszawa 2000, s. 29.
} 
autorefleksji (uzależnieni), to jednak nie były bardziej świadome swoich myśli i uczuć (osoby zdrowe). Jak podają w swojej koncepcji samoregulacji R.F. Baumeister, T.F. Heatherton i D.M. Tice, prowadzi to do osłabienia procesu monitorowania własnego zachowania, a tym samym do obniżenia lub utraty kontroli nad nim ${ }^{6}$.

Coraz częściej podkreśla się w piśmiennictwie znaczenie obrazu siebie u osób podejmujących zachowania ryzykowne, w tym o charakterze nałogowym ${ }^{7}$.

Celem przeprowadzonych badań, których rezultaty zostały zaprezentowane w niniejszym artykule, jest porównanie struktury obrazu siebie osób uzależnionych (U) i nieuzależnionych (NU) od Internetu. W badaniu wzięli udział sami mężczyźni.

\section{METODOLOGIA BADAŃ}

Materiał badawczy został zebrany w okresie od kwietnia do lipca 2019 roku. Zastosowano dobór celowy do grup. Pierwszą grupę stanowiły osoby uzależnione od Internetu biorące udział $\mathrm{w}$ podstawowym programie leczenia (grupa U). Grupę porównawczą stanowią osoby nieuzależnione (grupa NU). W badaniu wzięło udział 158 osób, z czego 136 testów uwzględniono w dalszych analizach statystycznych (w grupie $\mathrm{U}$ odpowiednio $\mathrm{N}=70,51,47 \%$ badanych osób; w grupie NU N=66, 48,53\% badanych osób). Przedział zmienności wieku w badanej grupie zawierał się pomiędzy 20 a 39 r.ż. $(M=24,55)$. Większość badanych mężczyzn, uzależnionych od Internetu, to osoby w wieku od 20-31 lat, z wykształceniem średnim lub wyższym, uczące się lub pracujące umysłowo, pochodzące z miast powyżej 100 tys. mieszkańców. Powyższe dane potwierdzają wyniki badań prowadzonych przez A. Jakubika

\footnotetext{
${ }^{6}$ Baumeister, Heatherton i Tice wymieniają liczne mechanizmy, które mogą być przyczyną kłopotów w kontroli działania w sytuacji uzależnień, wskazują przy tym na: sprzeczne standardy, czyli konfliktowe dążenia, cele czy powinności osoby. Gdy ta zmaga się ze sprzecznymi celami, wówczas raczej dochodzi do ruminacji (rozmyślania na jakiś temat) niż do konkretnych działań; brak monitorowania siebie - zanik oceny i samoświadomości własnej osoby; brak własnej woli może ona wynikać z właściwości charakterologicznych osoby, utraty jej rezerw siłowych oraz siły samego impulsu (siła napędu) do działania; inercja psychologiczna - polega na tym, że trudno powstrzymać niepożądane działanie w toku dłuższego jego trwania, łatwiej zaprzestać go na samym początku; uwaga oraz jej zależność z działaniem (R. BAUMEISTER, T. HEATHERTON i D. Tice, Utrata kontroli, s. 62).

${ }^{7}$ M. O'MOORE, C. KIRKHAM, Self-Esteem and its relationship to bullying behavior, ,Aggressive Behavior" 2001, nr 27, s. 271.
} 
z których wynika, iż z Internetu w przeważającej większości korzystają mężczyźni, mieszkańcy dużych miast, studiujący ${ }^{8}$.

W badaniu zastosowano następujące skale:

1. Kwestionariusz socjodemograficzny.

2. Test Uzależnienia od Internetu (Internet Addiction Test) autorstwa K. Young. W wersji oryginalnej składa się on z 20 pytań dotyczących symptomów uzależnienia od Internetu. Odpowiedzi udzielane są na pięciostopniowej skali: 0 - „,nie dotyczy”, 1 - ,,sporadycznie”, 2 - ,,rzadko”, 3 - „,czasami”, 4 „często”, 5 - „,zawsze”. Zgodnie z przyjętymi przez K. Young kryteriami za wyniki niskie (niskie ryzyko uzależnienia od Internetu, brak zagrożenia patologicznym użytkowaniem) uznaje się zakres 20-49 punktów, z kolei za wyniki średnie (średni stopień ryzyka uzależnienia od Internetu; zagrożenie patologicznym użytkowaniem - zakres 50-79, natomiast za wyniki wysokie, świadczące o patologicznym użytkowaniu Internetu (wysoki stopień ryzyka uzależnienia od Internetu), wynik powyżej 80 . W badaniach własnych zastosowano wersję oryginalną narzędzia.

3. Test Przymiotnikowy H.B. Gougha i A.B. Heilibruna (ACL). Test zaliczany jest do metod kwestionariuszowych, badających między innymi (realny i idealny) obraz siebie. 37-punktowej wersji testu, w polskim tłumaczeniu $\mathrm{i}$ adaptacji Z. Płużek. Wersja ta została wykorzystana w prezentowanych badaniach. Test składa się z 300 przymiotników, które służą do opisu osobowości i odnoszą się do szerokiego zakresu ludzkich cech i zachowań. Zadaniem badanego jest zaznaczenie tych przymiotników, które określają go najlepiej, badania „, ja realnego”, realnego obrazu siebie ${ }^{9}$.

Problem badawczy dotyczył istnienia różnic w strukturze obrazu siebie u mężczyzn uzależnionych i nieuzależnionych od Internetu.

$\mathrm{W}$ odniesieniu do tak postawionego problemu sformułowano następującą hipotezę:

- Istnieją różnice w strukturze obrazu siebie u mężczyzn uzależnionych i nieuzależnionych od Internetu.

\section{ANALIZA WYNIKÓW BADAŃ}

Na podstawie wyników badań uzyskanych w Teście Uzależnienia od Internetu K. Young podzielono badanych na dwie podgrupy:

\footnotetext{
${ }^{8}$ A. JAKUBIK, Zespót uzależnienia od Internetu, „Studia Psychologica UKSW” 2002, nr 3, s. 133.

${ }^{9}$ H.G. Gough, A.B. Heilbrun, The Adjective Check List. Manual 1980 Edition, Palo Alto 1980.
} 
- Grupa I - mężczyźni nieuzależnieni od Internetu, prawidłowe używanie Internetu (niski stopień ryzyka uzależnienia od Internetu (20-49 punktów); $\mathrm{NU}(\mathrm{N}=66)$.

- Grupa II - mężczyźni uzależnieni od Internetu, patologiczne używanie Internetu (wysoki stopień ryzyka uzależnienia od Internetu (80-100 punktów); $\mathrm{U}(\mathrm{N}=70)$.

W oparciu o powyższy podział na stopień zaangażowania w Internet, dokonano analizy interpretacyjnej struktury obrazu siebie osób badanych. W poniższych tabelach zestawiono otrzymane wyniki. Średnie wyniki uzyskane w obrazie siebie u osób uzależnionych i nieuzależnionych przedstawiono na wykresie 3.1.

Wykres 3.1. Obraz siebie (Ja realne) w badanej grupie internautów (ACL)
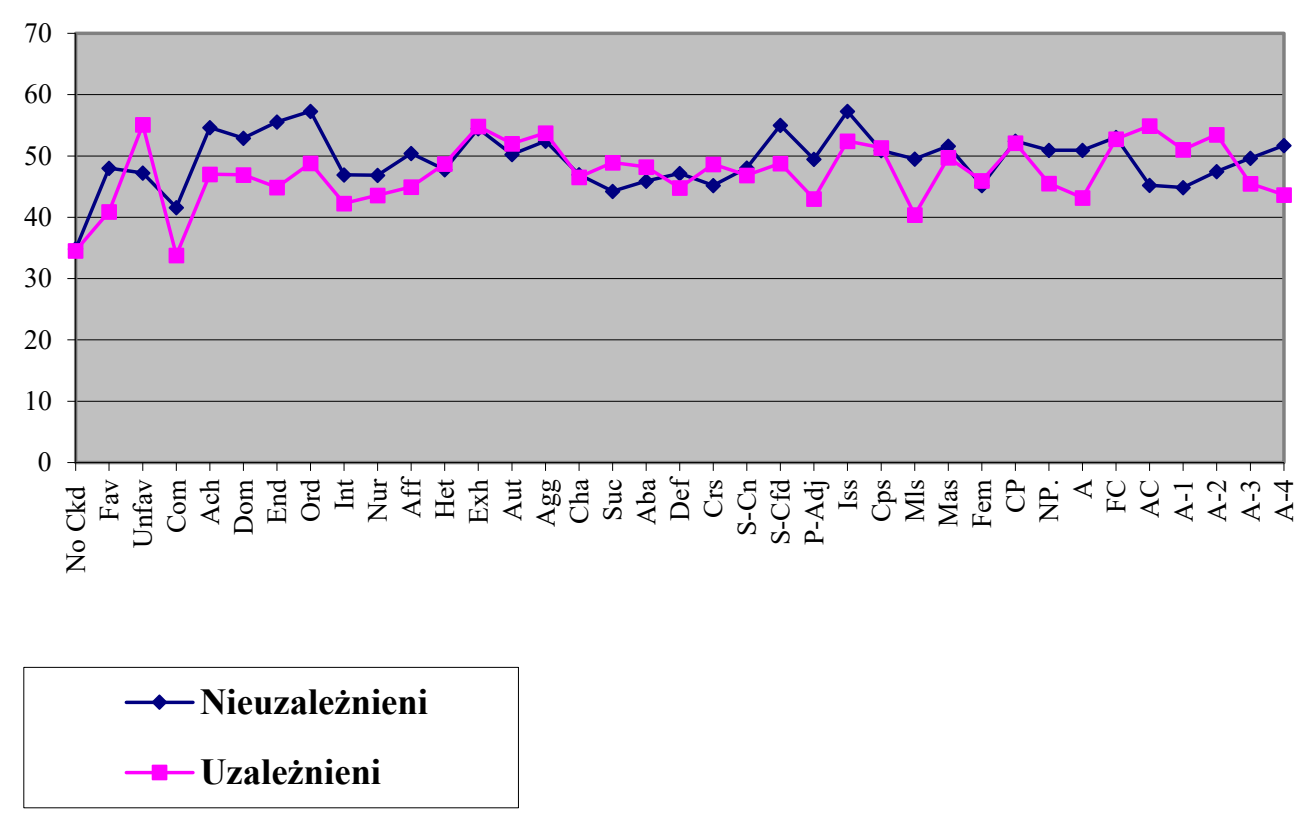

Skale modus operandi - porównanie grup

$\mathrm{Z}$ analizy danych zwartych w tabeli 3.1. wynika, że istnieją istotne różnice w obrazie siebie pomiędzy uzależnionymi a nieuzależnionymi mężczyznami w skalach Fav, UnFav i Com, co wskazuje, iż osoby wolne od internetowej zależności postrzegają siebie jako bardziej taktowne, mniej osądzające i skłonne do obrażania się niż mężczyźni uzależnieni (UnFav, p=0,000). Badani ci wykazują się lepszym przystosowaniem do nowych sytuacji oraz większą skłonnością do otaczania opieką innych (Fav, p=0,000). Uzależnieni 
mężczyźni widzą siebie jako zniechęconych i pełnych lęku o przyszłość. Odrzucanie siebie prowadzi u nich do poczucia zawziętości i wrogości wobec innych ludzi. Osoby nieuzależnione są wolne od roszczeń w relacjach interpersonalnych, pogodnie znoszą niepowodzenia.

Tabela 3.1. Średnie wyniki w skalach modus operandi uzyskane przez badanych

\begin{tabular}{|c|c|c|c|c|c|c|}
\hline \multirow{3}{*}{ Skale ACL } & \multicolumn{4}{|c|}{ Kategorie badanych } & \multicolumn{2}{|c|}{ Test $t$} \\
\hline & \multicolumn{2}{|c|}{ Uzależnieni (U) } & \multicolumn{2}{|c|}{ Nieuzależnieni (NU) } & \multirow[b]{2}{*}{$\mathbf{t}$} & \multirow[b]{2}{*}{$\mathbf{p}=$} \\
\hline & $\mathbf{M}$ & SD & $\mathbf{M}$ & SD & & \\
\hline No CKD & 34,57 & 4,279 & 34,86 & 5,023 & 0,366 & 0,715 \\
\hline Fav & 40,91 & 8,132 & 48,02 & 7,063 & 5,422 & 0,000 \\
\hline Unfav & 55,11 & 11,020 & 47,24 & 7,581 & $-4,825$ & 0,000 \\
\hline Com & 33,81 & 9,265 & 41,58 & 7,646 & 5,311 & $\overline{0,000}$ \\
\hline
\end{tabular}

\section{Skale potrzeb - porównanie grup}

W skalach potrzeb istotne różnice wystąpiły w siedmiu czynnikach: Ach, Dom, End, Ord, Int, Aff i Suc (tabela 3.2). Badani z grupy NU są bardziej pracowici i ukierunkowani na realizacje celów. Posiadają silną wolę, są zdecydowani i wolni od zwątpienia w siebie w dążeniu do celu (Ach, $\mathrm{p}=0,000$; Dom, $p=0,000)$. W większej mierze niż osoby uzależnione cechuje ich poczucie obowiązku oraz preferowanie zadań wymagających wysiłku i dyscypliny (End, $\mathrm{p}=0,000$; Dom, p=0,000). Przywiązują oni większą wagę do analizy myślowej, mają szersze horyzonty i większą zdolność przezwyciężania stresu i traumy (Int, p=0,001). Czują się swobodnie w kontaktach towarzyskich, łatwo przystosowują się do zmiennych sytuacji grupowych (Aff, $\mathrm{p}=0,000$ ). Nieuzależnionych internautów, w przeciwieństwie do grupy obciążonej nałogiem, cechuje skłonność do racjonalizacji i obiektywizm (Ord, p=0,000). Mężczyźni uzależnieni unikają konfrontacji z „,nowym”, preferują strategie ucieczkowe, nie czują się kompetentni w przezwyciężaniu sytuacji trudnych (Suc, $\mathrm{p}=0,002$ ). 
Tabela 3.2. Średnie wyniki w skalach potrzeb uzyskane przez badanych

\begin{tabular}{|c|c|c|c|c|c|c|}
\hline \multirow{2}{*}{ Skale ACL } & \multicolumn{3}{|c|}{ Kategorie badanych } & \multicolumn{2}{c|}{ Test t } & \multirow{2}{*}{ : $=$} \\
\cline { 2 - 5 } & \multicolumn{2}{|c|}{ Uzależnieni (U) } & \multicolumn{2}{c|}{ Nieuzależnieni (NU) } & & \\
\cline { 2 - 6 } & M & SD & M & SD & & \\
\hline Ach & 47,65 & 8,427 & 54,65 & 8,933 & 5,121 & $\mathbf{0 , 0 0 0}$ \\
\hline Dom & 46,93 & 8,100 & 52,89 & 8,835 & 4,108 & $\mathbf{0 , 0 0 0}$ \\
\hline End & 44,90 & 8,171 & 55,56 & 8,088 & 7,642 & $\mathbf{0 , 0 0 0}$ \\
\hline Ord & 48,84 & 9,040 & 57,30 & 8,788 & 5,529 & $\mathbf{0 , 0 0 0}$ \\
\hline Int & 42,26 & 8,163 & 46,94 & 7,493 & 3,479 & $\mathbf{0 , 0 0 1}$ \\
\hline Nur & 43,60 & 6,885 & 46,85 & 6,971 & 2,733 & 0,007 \\
\hline Aff & 44,97 & 7,514 & 50,42 & 7,874 & 4,132 & $\mathbf{0 , 0 0 0}$ \\
\hline Het & 48,71 & 9,891 & 47,77 & 8,852 & $-0,584$ & 0,560 \\
\hline Exh & 54,84 & 7,558 & 54,48 & 8,542 & $-0,259$ & 0,796 \\
\hline Aut & 52,01 & 7,214 & 50,24 & 8,326 & $-1,329$ & 0,186 \\
\hline Agg & 53,74 & 8,127 & 52,42 & 8,295 & $-0,936$ & 0,351 \\
\hline Cha & 46,54 & 7,859 & 46,97 & 8,042 & 0,313 & 0,755 \\
\hline Suc & 48,94 & 9,287 & 44,24 & 7,942 & $-3,163$ & $\mathbf{0 , 0 0 2}$ \\
\hline Aba & 48,23 & 9,409 & 45,89 & 10,036 & $-1,400$ & 0,164 \\
\hline Def & 44,81 & 8,352 & 47,15 & 9,118 & 1,560 & 0,121 \\
\hline
\end{tabular}

\section{Skale tematyczne - porównanie grup}

Analiza danych zawartych w tabeli 3.3. wskazuje, że osoby wolne od internetowej zależności są inicjatorami działań, mającymi zaufanie do swoich zdolności w osiąganiu celów. Postrzegają siebie jako stanowczych i przedsiębiorczych ( $\mathrm{S}-\mathrm{Cfd}, \mathrm{p}=0,000)$. Spokój i stabilność uczuciowa pozwala im stawić czoła napięciom i stresom (P-Adj, $\mathrm{p}=0,000)$. Mężczyzn nieuzależnionych charakteryzuje duża efektywność grupowa, element narcystycznego rozbudowanego własnego ja (Iss, $p=0,002$ ). Zorganizowanie i umiejętność planowania pozwala im wypełnić wszelkie powinności (Mls, p=0,000). Mężczyźni uzależnieni od Internetu mają trudności w mobilizowaniu własnego potencjału. Są zahamowani i skryci, lękowo prognozują przyszłość. Trudności sprawia im ustalenie i osiąganie zamierzonych celów. 
Tabela 3.3. Średnie wyniki w skalach tematycznych uzyskane przez badanych

\begin{tabular}{|c|c|c|c|c|c|c|}
\hline \multirow{2}{*}{ Skale ACL } & \multicolumn{4}{|c|}{ Kategorie badanych } & \multicolumn{2}{c|}{ Test t } \\
\cline { 2 - 5 } & \multicolumn{2}{|c|}{ Uzależnieni } & \multicolumn{2}{c|}{ Nieuzależnieni } & t & p= \\
\cline { 2 - 5 } & M & SD & M & SD & & \\
\hline Crs & 48,67 & 8,634 & 45,20 & 9,132 & $-2,281$ & 0,024 \\
\hline S-Cn & 48,87 & 7,998 & 48,05 & 9,054 & 0,802 & 0,424 \\
\hline S-Cfd & 48,81 & 9,648 & 55,02 & 9,015 & 3,867 & $\mathbf{0 , 0 0 0}$ \\
\hline P-Adj & 43,01 & 8,725 & 49,48 & 7,095 & 4,728 & $\mathbf{0 , 0 0 0}$ \\
\hline Iss & 52,44 & 8,973 & 57,30 & 8,638 & 3,215 & $\mathbf{0 , 0 0 2}$ \\
\hline Cps & 51,34 & 7,487 & 50,91 & 9,753 & $-0,929$ & 0,771 \\
\hline Mls & 40,40 & 8,199 & 49,52 & 7,218 & 6,865 & $\mathbf{0 , 0 0 0}$ \\
\hline Mas & 49,76 & 8,254 & 51,61 & 9,338 & 1,225 & 0,223 \\
\hline Fem & 45,97 & 8,313 & 45,20 & 7,368 & $-0,574$ & 0,576 \\
\hline
\end{tabular}

\section{Skale analizy transakcyjnej - porównanie grup}

W trzech czynnikach (NP, A, AC) w skalach analizy transakcyjnej wystąpiła różnica istotna statystycznie między uzależnionymi i nieuzależnionymi (tabela 3.4). Mężczyźni wolni od nałogu wykazują większą skłonność do podtrzymywania kontaktów interpersonalnych opartych na szacunku (NP, p=0,000), w przeciwieństwie do uzależnionych internautów skutecznie stawiają czoła wymaganiom pracy $(\mathrm{A}, \mathrm{p}=0,000)$, są niezależni i pewni siebie $(\mathrm{AC}, \mathrm{p}=0,000)$. Mężczyźni z grupy ryzyka uzależnienia poszukują zmiany i różnorodności, będący jednocześnie zalęknionymi i mało odpornymi na stres. Uzależnieni internauci wykazują się większą wrażliwością niż nieuzależnieni badani, ale są przy tym mniej skuteczni w powinnościach zawodowych. Mężczyźni ci szukają zadowolenia w sferze marzeń, nie zaś w wymagającym kontekście aktualnej sytuacji (NP, A, AC).

Tabela 3.4. Średnie wyniki w skalach analizy transakcyjnej uzyskane przez badanych

\begin{tabular}{|c|c|c|c|c|c|c|}
\hline \multirow{2}{*}{ Skale ACL } & \multicolumn{4}{|c|}{ Kategorie badanych } & \multicolumn{2}{c|}{ Test t } \\
\cline { 2 - 5 } & \multicolumn{2}{|c|}{ Uzależnieni } & \multicolumn{2}{c|}{ Nieuzależnieni } & \multirow{2}{*}{ t } & p= \\
\cline { 2 - 5 } & M & SD & M & SD & & \\
\hline CP & 52,13 & 8,632 & 52,42 & 9,199 & 0,193 & 0,847 \\
\hline NP & 45,53 & 7,115 & 50,95 & 6,543 & 4,621 & $\mathbf{0 , 0 0 0}$ \\
\hline A & 43,20 & 8,546 & 50,92 & 6,922 & 5,771 & $\mathbf{0 , 0 0 0}$ \\
\hline FC & 52,76 & 7,928 & 53,05 & 8,674 & 0,202 & 0,840 \\
\hline AC & 54,91 & 8,079 & 45,21 & 8,433 & $-6,852$ & $\mathbf{0 , 0 0 0}$ \\
\hline
\end{tabular}




\section{Skale Oryginalności - Inteligencji - porównanie grup}

$\mathrm{W}$ skalach oryginalności-inteligencji różnica istotna statystycznie wystąpiła w trzech czynnikach: A-1, A-2 i A-4 (tabela 3.5). W badanej grupie osoby nieuzależnione od Internetu są czujne i rozważne. Badani ci są nieustępliwi w kwestiach etycznych (A-1, p=0,000). Charakteryzuje ich praktyczność, przewidywalność $(A-2, p=0,000)$ i zdolność do podjęcia planowanej i wytężonej pracy koniecznej dla osiągania racjonalnych celów $(\mathrm{A}-4, \mathrm{p}=0,000)$. Mężczyźni uzależnieni od Internetu wykazują się dużą dbałością o własną pozycję, są popędliwi i łatwo rozpraszają uwagę. Potrafią być samowystarczalni i oryginalni w myśleniu. Charakteryzuje ich mniejsze niż nieuzależnionych mężczyzn zdyscyplinowanie wewnętrzne, mniejsza kontrola i łatwe poddawanie się irracjonalnym troskom. Nie dają sobie oparcia w sytuacjach trudnych.

Tabela 3.5. Średnie wyniki w skalach Oryginalności - Inteligencji uzyskane przez badanych

\begin{tabular}{|c|c|c|c|c|c|c|}
\hline \multirow{2}{*}{ Skale ACL } & \multicolumn{4}{|c|}{ Kategorie badanych } & \multicolumn{2}{c|}{ Test t } \\
\cline { 2 - 5 } & \multicolumn{2}{|c|}{ Uzależnieni } & \multicolumn{2}{|c|}{ Nieuzależnieni } & \multirow{2}{*}{ t } & p= \\
\cline { 2 - 5 } & M & SD & M & SD & & \\
\hline A-1 & 51,03 & 9,190 & 44,86 & 7,549 & $-4,260$ & $\mathbf{0 , 0 0 0}$ \\
\hline A-2 & 53,47 & 9,057 & 47,47 & 7,814 & $-4,127$ & $\mathbf{0 , 0 0 0}$ \\
\hline A-3 & 45,50 & 9,128 & 49,64 & 8,283 & 2,762 & 0,007 \\
\hline A-4 & 43,66 & 7,918 & 51,71 & 8,065 & 5,876 & $\mathbf{0 , 0 0 0}$ \\
\hline
\end{tabular}

\section{WNIOSKI}

W prezentowanych badaniach analizie poddano percepcję takich potrzeb i cech osobowości mężczyzn uzależnionych i nieuzależnionych od Internetu, jak: typowość (Com), potrzeba osiągnięć (Ach), potrzeba dominacji (Dom), potrzeba wytrwałości (End), potrzeba porządku (Ord), potrzeba rozumienia siebie, innych (Int), potrzeba opiekowania się innymi (Nur), potrzeba afiliacji (Att), potrzeba kontaktów z osobami płci przeciwnej (Het), potrzeba ujawniania siebie (Exh), potrzeba autonomii (Aut), potrzeba agresji (Agg), potrzeba zmiany (Cha), potrzeba wsparcia ze strony innych (Suc), potrzeba upokorzenia siebie (Aba), potrzeba uległości (Def), gotowość do poddania się poradnictwu psychologicznemu (Crs), samokontrola ( $\mathrm{S}-\mathrm{Cn}$ ), zaufanie do siebie (S-Cfd), przystosowanie osobiste (P-Adj), skala idealnego obrazu siebie (Iss), skala 
osobowości twórczej (Cps), skala zdolności przywódczych (Mls), skala męskości (Mas), skala kobiecości (Fem), krytyczny rodzic (CP), wychowujący rodzic (NP), dorosły (A), wolne dziecko ( $\mathrm{Fc}$ ), przystosowane dziecko (Ac), wysoka oryginalność i niska inteligencja (A-1), wysoka oryginalność i wysoka inteligencja (A-2), niska oryginalność i niska inteligencja (A-3), niska oryginalność i wysoka inteligencja (A-4) ${ }^{10}$.

Analiza wyników badań potwierdziła postawioną hipotezę. Ujawniła istnienie różnic $\mathrm{w}$ realnym obrazie siebie mężczyzn uzależnionych i nieuzależnionych od Internetu, w zakresie wszystkich cech obrazu siebie ujętych w Teście Przymiotnikowym ACL H.B. Gougha i A.B. Heilibruna.

Mężczyźni nieuzależnieni od Internetu, w przeciwieństwie do mężczyzn uzależnionych, postrzegają siebie jako godnych zaufania, taktownych i mniej osądzających (UnFav). Posiadają większą łatwość przystosowania się, są ustępliwi, opiekuńczy i pogodnie znoszą niepowodzenia (Fav, Com). Mężczyźni wolni od internetowego nałogu przejawiają silną wolę, są nastawieni na realizację odległych celów, mają wysoką motywację do sprostania zadaniom i gotowość do podejmowania wysiłku (Ach), nie przejmują się dezaprobatą otoczenia, cechuje ich towarzyskość i umiejętności przywódcze (Dom). Uzależnieni mężczyźni działają nieśpiesznie (End), mniej cenią sobie analizę myślową (Int). Cechuje ich sztywność w kontaktach towarzyskich (Aff). Nieuzależnieni badani wykazują się silną dążnością do obiektywizmu, racjonalizują zdarzenia (Ord), uzależnieni zaś często czują się bezradni w zmaganiu się ze stresem i kryzysem (Suc), oczekują szybkiej gratyfikacji i znajdują przyjemność w ,tu i teraz” (Ord) ${ }^{11}$.

Badani nieuzależnieni internauci są pełni inicjatywy i wiary w swoje zasoby osobiste (S-Cfd), działają stabilnie i bez napięć (P-Adj); w przeciwieństwie do uzależnionych mężczyzn są silnie skoncentrowani na sobie (Iss) i cechuje ich względny brak przywiązania do tego, co myślą inni. Mężczyźni uzależnieni nie stawiają przed sobą wyzwań, (Mls), nie dążą do sprawdzania siebie, ta cecha utrudnia wytrwanie w procesie terapeutycznym, niechętnie szukają pomocy specjalistycznej, mają trudności w uruchamianiu swoich zasobów osobistych, często stawiają opór przed zmianą. Gorzej radzą sobie z odpowiedzialnością wynikającą z dorosłości (A). Mężczyźni z grupy niskiego ryzyka uzależnienia działają skutecznie i rozważnie, nie boją się życia i wyzwań,

${ }^{10}$ A. JUROS, P. OlEŚ, Z. WuJEC, Struktura czynnikowa i skupieniowa testu ACL H.G. Gougha i A.B. Heilbruna (Przydatność dla diagnostyki psychologicznej), w: Z psychometrycznych problemów diagnostyki psychologicznej, red. J. Brzeziński, E. Hornowska, Poznań 1993, s. 11.

${ }^{11}$ Znajduje to potwierdzenie w badaniach nad Zespołem Niedoboru Nagradzania u osób uzależnionych od Internetu. 
jakie ono przed nimi stawią (AC), znajdują oparcie w dobrych relacjach z innymi (NP).

Mężczyźni, obciążeni internetowym nałogiem, bywają bardziej popędliwi od mężczyzn wolnych od uzależnienia (A1), ci są czujni i rozważni. Odczuwają rozczarowanie sobą (A2). Nieuzależnieni internauci są zdyscyplinowani i gotowi do planowania i utrzymania działania, uzależnieni mają mniejszą samokontrolę, bywają zmienni (A4).

\section{ZAKOŃCZENIE}

Rezultaty zaprezentowanych badań potwierdziły, iż mężczyźni uzależnieni (uczestniczący w podstawowym programie leczenia) i nieuzależnieni od Internetu znamiennie różnią się od siebie w wielu aspektach obrazu siebie.

Ze względu na wielkość i dobór próby badawczej (badania dotyczyły samych mężczyzn), nieuprawnione byłoby uogólnianie wniosków niniejszych badań poza zbadaną populację mężczyzn. Osiągnięte rezultaty częściowo korespondują jednak z innymi analizami empirycznymi dotyczącymi osób uzależnionych. Szczególnie istotną informacją - płynącą z przeprowadzonych badań - z perspektywy praktycznej wydaje się być fakt, iż możliwa jest zmiana parametrów obrazu siebie osób uzależnionych od Internetu poprzez odpowiednie oddziaływania profilaktyczne i terapeutyczne ${ }^{12}$. Poznanie specyfiki funkcjonowania mężczyzn uzależnionych od Internetu, w tym ich obrazu siebie, umożliwi profesjonalne wspieranie tej grupy osób ryzyka w przezwyciężaniu internetowego nałogu i wspieraniu procesu zdrowienia.

\section{BIBLIOGRAFIA}

BAumeister R., HeAtherton T., Tice D., Utrata kontroli. Jak i dlaczego tracimy zdolność samoregulacji, Państwowa Agencja Rozwiązywania Problemów Alkoholowych, Warszawa 2000.

Gough H.G., HeIlbrun A.B., The Adjective Check List. Manual 1980 Edition, Consulting Psychologists Press, Palo Alto 1980.

JAKUBIK A., Zespół uzależnienia od Internetu, „Studia Psychologica UKSW” 3(2002), s. 133-142.

Juros A., Oleś P., Wujec Z., Struktura czynnikowa i skupieniowa testu ACL H.G. Gougha i A.B. Heilbruna (Przydatność dla diagnostyki psychologicznej), w: Z psychometrycznych problemów

\footnotetext{
${ }^{12}$ Mroziak B., Woronowicz B., WóJTowicz S., Zmiany poczucia koherencji i stylu radzenia sobie ze stresem po podstawowym programie psychoterapii osób uzależnionych od alkoholu, „Alkoholizm i Narkomania” 35(1999), nr 2, s. 225-236.
} 
diagnostyki psychologicznej, red. J. Brzeziński, E. Hornowska, Wydawnictwo Naukowe UAM, Poznań 1993.

Kostrubiec B., Obrazy postmodernizmu, Wydawnictwo KUL, Lublin 2004.

KozIELECKi J., Koncepcje psychologiczne człowieka, Wydawnictwo Akademickie Żak, Warszawa 1995.

Mroziak B., Woronowicz B., WóJTowicz S., Zmiany poczucia koherencji i stylu radzenia sobie ze stresem po podstawowym programie psychoterapii osób uzależnionych od alkoholu, „Alkoholizm i Narkomania" 35(1999), nr 2, s. 225-236.

O’Moore M., Kirkham C., Self-Esteem and its relationship to bullying behavior, „Aggressive Behavior" 2001, nr 27, s. 269-283.

Strelau J., Podręcznik akademicki, t. II. Podstawy psychologii, Gdańskie Wydawnictwo Psychologiczne, Gdańsk 2004.

Young K.S., Addictive Use of The Internet: A Case Study that Breaks The Stereotype, „Psychological Reports" 79(1996), s. 899-902.

\section{OBRAZ SIEBIE U MĘŻCZYZN UZALEŻNIONYCH OD INTERNETU. ANALIZA PORÓWNAWCZA}

\section{STRESZCZENIE}

Obraz siebie stanowi osiowy element struktury osobowości człowieka, regulujący jego postępowanie. Odgrywa istotną rolę $\mathrm{w}$ procesie samoregulacji. Uzależnienie od Internetu jest zaburzeniem, w którym podstawowym objawem jest utrata zdolności samoregulacyjnych, kontroli swoich zachowań w relacji z maszyną, która jest efektem między innymi działania mechanizmów zniekształcających percepcję samego siebie. W artykule zaprezentowane zostały wyniki analizy porównawczej przeprowadzonej na grupie 70 mężczyzn uzależnionych od Internetu oraz 66 mężczyzn nieuzależnionych, w obrębie struktury obrazu siebie mierzonej za pomocą Testu Przymiotnikowego H.B. Gougha i A.B. Heilibruna (ACL). Wyniki badań wskazują, że występują istotne statystycznie różnice w strukturze obrazu siebie w obrębie obu grup. Dobór celowy oraz mała liczebność próby $(\mathrm{N}=136)$ ograniczają zakres wnioskowania, niemniej mają one istotny walor aplikacyjny, wart uwzględnienia w projektowaniu oddziaływań profilaktycznych i terapeutycznych wzmacniających obszary deficytowe u osób uzależnionych.

Słowa kluczowe: obraz siebie; uzależnienie od Internetu. 